\title{
De Olympiske Lege år 2000 Et tilbageblik
}

\section{Af Søren Damkjoer}

De Olympiske Sommerlege blev i år 2000 afholdt i Manilla. Sportsligt vil Legene blive husket for Hua Zhuas højdespring på 2,50 meter og for Zhulikovs stangspring på 6,50 meter med den nye stang med zilan-fibre. Ellers var rekordforbedringerne få i de fleste idrætsgrene. Man har siden talt om $\gg$ tangeringernes Olympiade «, og der er ingen tvivl om, at Sommerlegene i Manilla fortjener denne betegnelse. Flere højdespringere havde jo allerede sprunget 2,49 ved den foregående Olympiade og ved Verdensmesterskaberne. Zilanfibrenes elastiske egenskaber var kendt, men det krævede en ændring af afviklingsteknikken, hvis disse egenskaber skulle kunne udnyttes fuldt ud. Det var forskerne ved Kievs Institut for Biomekanik, der fandt på at benytte tungere atleter og samtidig ændre kroppens hældningsgrad, når stangen videregav sin elastiske energi. Nogle talte om »katapultstangen « og dens farlighed, fordi selv små fejl medførte, at stangspringeren ville havne uden for skumgraven.

Sommerlegene havde for første gang konkurrencer i Amerikansk Fodbold, som på få år havde vundet en utrolig popularitet i Europa, Oceanien; den Russiske Føderation og Afrika. Det Internationale Netværk havde arbejdet ihærdigt for, at denne medievenlige sportsgren blev indført. Der er ingen tvivl om, at denne sportsgren reddede legenes $\emptyset$ konomi. De traditionelle atletikdiscipliner havde i nogen grad mistet deres appel. Der var som nævnt blevet længere mellem verdensrekorderne og de olympiske rekorder. Der var også for få mediepersonligheder blandt udøverne. Nogle forskere talte allerede i 1992 om, at de videnskabelige træningsmetoder fjernede stjernepersonligheden.

Den skandalerække, der blev indledt i Los Angeles med diverse kollaps-syndromer, blev fortsat og har åbenbart ikke kunnet standses indtil i dag. I Manilla døde 4 ryttere i mændenes $100 \mathrm{~km}$ holdkonkurrence i cykling, formentlig af hedeslag og væskemangel. Det skete tæt på opløbet, og TV kom derved til at vise hele den tragiske hændelse. Bagefter truede NBC-AC med helt at trække sig ud, hvis skandalerne fortsatte, hvad de som bekendt har gjort. Det blev aldrig klarlagt, om de dragter, det amerikanske hold benyttede, havde medvirket til hedeslagene. Det slimlignende lag, der skulle nedsætte frikti- 
onen mellem luften og dragten havde ganske vist milliarder af mikroporer. Men senere fors $\emptyset \mathrm{g}$ har vist, at de kan tilstoppes af urenheder fra sveden. Men ingen tænkte dengang på at få hevet dragterne af rytterne i de kritiske sekunder.

Desværre er skandaler af den type blevet en fast bestanddel af Olympiaderne. I 2016 i Madras ramte skandalerne igen både marathonløb og cykling.

I Manilla deltog der for første gang atleter, der var produceret ved hjælp af de forplantningsteknikker, der blev udviklet i 70'erne og begyndelsen af 80 'erne i forrige århundrede. Hvad ingen dengang vidste udover et lille antal forskere og sportsledere var, at de første vellykkede eksperimenter i virkeligheden blev gennemført med topatleter. Aliogenese, altså befrugtning af æg uden for moderorganismens forplantningssystem og inplantering $\mathrm{i}$ en »fremmed « livmoder, blev dengang kaldt »rugemodermetoden«. Løberen Jean Delfors var formentlig et produkt af denne forplantningsteknik, men de biologiske forældres navne blev aldrig afsløret. Længdespringeren Bill Salitos far var Hain Hansson og moderen var Angelica Spruce, begge allround atleter, men han blev født af Jean Salito, der kun dyrkede lidt motionsidræt. Disse atleter placerede sig dog ikke i Manilla blandt de ti bedste i deres discipliner. Først i Buenos Aires fik Bill Salito en sølvmedalje. Dette forårsagede, da det blev kendt i selve Olympiadeåret, en livlig diskussion og trusler om udelukkelse for »ovular-doping «, som det blev kaldt. Men metoden var da i det sidste årti så udbredt, at de fik lov til at deltage. Ved den seneste Olympiade $\mathrm{i}$ år 2020 var over 100 deltagere blandt de aktive i $\emptyset$ vrigt produceret ved aliogenese.

Hej moster! Hva' ska' du lave

$i$ aften - en »ovular-doping «

eller...?

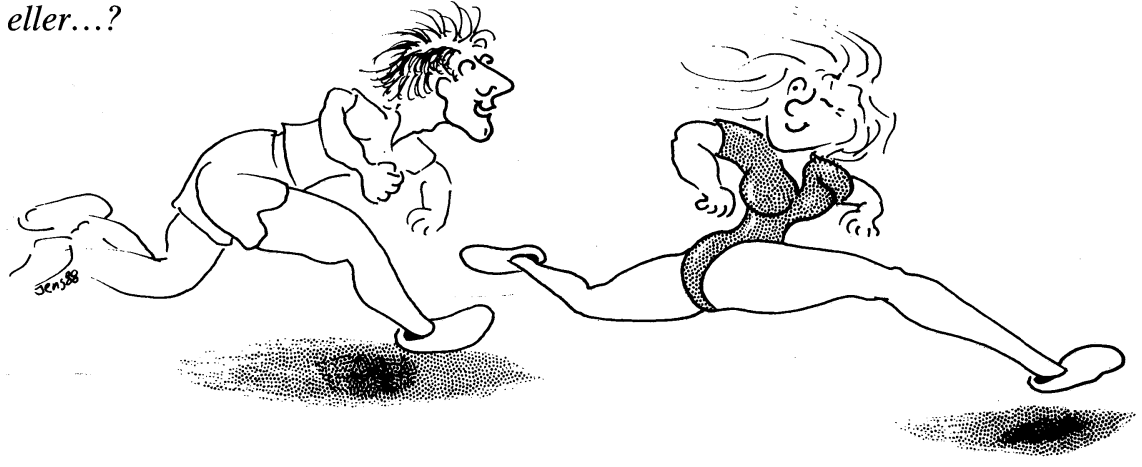

Vinterlegene optog for første gang de nye populære sportsgrene ski-racing og telemarksving, der på få år var blevet populære. Monoski var nu med for anden gang. Skiakrobatik havde været inkluderet siden 1992. Alle disse nye skigrene var blevet populære blandt den nye generation af TV-seere. Vinter- 
legene fandt sted i Kavkaskij Olympicheskij Centr, som Transkaukasien havde bygget med henblik på vinterlegene i forbindelse med en voldsom satsning på vinterturismen. Vinterlegene var vokset så meget, at de traditionelle skisportssteder havde vanskeligt ved at huse en vinterolympiade af det omfang, så Olympicheskij Centr løste et efterhånden tilbagevendende problem. Den olympiske ild blev tændt med røngtenlaser fra satelitten Olympos, der transmitterede en plasmagenereret laser fra Emittor-1 ved Olympia ned til en receptor på toppen af Elbrus og videre til Kavkaskij Centr.

Endvidere huskes legene for den første holocinografiske udsendelse, der blev sendt til Euroasien og Nordamerika, hvor omkring 80 millioner kunne se en holocinografisk transmission af skiakrobatik og skiracing.

\section{En succes}

Da Præsident Zinoidov erklærede Legene for åbnet $i$ år 2000, var der gået et tiår med at give dem et nyt image. Zinoidov skulle videreføre en succes, der var ved at kvæle sig selv. Kriseårene i 70'erne og 80'erne var overvundet i 1988, men den $\varnothing$ konomiske styring af Legene i Soul havde været problematisk. Den såkaldte Los Angeles model (efter legene i Los Angeles i 1984) var heller ikke holdbar længere. Legene skulle ganske vist k $\varnothing$ res som en forretning, men forretningen var firdoblet siden, og konkurrencen fra andre sportsarrangementer var blevet hårdere. I årevis havde de nationale Olympiske Kommiteer krævet en større indflydelse, medens Zinoidov ville gøre de Olympiske Lege helt uafhængige. Det blev som bekendt Zinoidovs model, der løb af med sejren.

Olympiaden i år 2000 blev en succes, der ikke siden er overgået. Seertallet anslåes til næsten 3 milliarder, og déltagerantallet er ikke siden blevet overgået. Også den politimæssige og militære overvågning var den største og mest velplanlagte hidtil. 30.000 betjente og soldater var udkommanderet, ledet af den nyskabelse der diskret var oprettet ved legene i 1992, d.v.s. en Olympisk Sikkerhedskommite direkte under Zinoidovs kontrol.

\section{Financieringen}

Financieringen af Sommerlegene fortjener en særlig omtale. Sydfraktionen i IOC, der som betegnelsen antyder bestod af Oceanien, Afrika og Sydamerika havde i næsten et årti krævet, at legene blev financieret på en ny måde. Det var betingelsen for at de kunne holdes udenfor de nordlige industrimetropoler. Financieringen blev derfor udliciteret til et Olympisk Konsortium bestående af det Oceaniske Netværk, NBC-AC, det Socialistiske Informationsselskab og den Globale Bank. Budgettet var i år 2000 svulmet op til den uhørte sum af 25 milliarder Internationale Enheder (IE), så en ny financieringsform skulle findes, uanset hvor legene skulle afholdes. Konsortiet byggede selv det Oceaniske Stadion, som efter legene blev leaset til det Oceaniske Statssamfund. 
I to årtier før årtusindskiftet havde truslen om boykot og de faktiske boykotter bestandigt gjort planlægningen af legene vanskelig. Erindringen om Moskva 1980 og Los Angeles 1984 var levende, og den mere og mere udbredte tale om de Olympiske Leges financielle kvælning havde gjort sponsorer og TV-netværkerne ekstremt forsigtige. Så Legene måtte finde en ny form for organisation og financiering. Enkelte nationer, der tidligere af velkendte grunde havde ofret et uhørt og ukendt milliardbel $\varnothing \mathrm{b}$ på at vinde prestige gennem Legene var blevet mere bevidste om omkostningerne. De var begyndt at begrænse eller omlægge deres investeringer i sportsudvikling med henblik på OL. Kort sagt måtte de Olympiske Lege finde en ny formel. Den nye formel blev »globalisering og uafhængighed «. Den nye formel og dens omsætning til virkelighed var i høj grad Zinoidovs fortjeneste. Han kom fra en kometagtig karriere i den tidlige fase af Sovjetunionens perestrojka og i det internationale diplomati. Med »globalisering « mente han, at de Olympiske Lege måtte løsrives fra den traditionelle rivalisering mellem stormagterne.

I det ord lå også, at den dominans, som den nordlige halvkugle havde haft, snarest muligt måtte brydes. Med »uafhængighed «mente han, at de Olympiske Lege måtte frigøre sig fra de nationale olympiske komiteers indflydelse. IOC måtte simpelthen selv kunne tilrette de Olympiske Lege hvorsomhelst i verden og finde den mest hensigtsmæssige måde at organisere og finansiere legene på. Når der i dag derfor er en særlig grund til at interessere sig for Legene $i$ år 2000 er det naturligvis, fordi det er denne formel, der siden har været den gældende. Jeg tror, at denne formel har bevirket, at legene har overlevet til i dag, år 2020. Derfor har de Olympiske Lege kunnet konkurrere med de nye tendenser i somakulturen.

Betegnelsen somakultur benytter jeg for det, der tidligere blev kaldt »idræt«, »sport « og »kropskultur «. Som bekendt har denne betegnelse i stigende grad vundet indpas i den videnskabelige diskussion af kropslige aktiviteter. Ligesom man i dag taler om soma-videnskab, bør man tale om somakultur for at undgå forrige århundredes terminologiske forvirring. Jeg vil senere omtale disse nye tendenser i somakulturen og den konkurrence, de har påført de Olympiske Lege. Når jeg derfor har sagt, at Zinoidovs formel gjorde, at Legene har kunnet overleve indtil i dag, skyldes det det overvældende bevismateriale. Men ingen kan i dag sige, om de Olympiske Lege vil overleve på længere sigt.

\section{Hvad har OL-2000 betydet?}

Selvom jeg har antydet nogle af de forhold, der gjorde OL-2000 til noget særligt, kunne man spørge, hvorfor man skal hæfte sig ved netop den Olympiade og ikke 100 års Jubilæumsolympiaden i 1996 ?

Som bekendt druknede OL-96 i så mange jubilæumsfestligheder og så meget ceremoniel, at det i dag er svært at se noget mønster. Det var et nostalgisk 
show af ekstraordinær karakter. Den antikke nostalgi gik over gevind i 96 og kom næsten ufrivilligt til at minde om den antik-kitsch, som blev iscenesat $\mathrm{i}$ Berlin 1936. Det var som om OL skulle igennem 100 år og så at sige fejre sig selv og sin fiktive oprindelse i det antikke forbillede for sidste gang. Det er derfor rimeligt at se på OL-2000 som det afgørende år for det, man kaldte den olympiske bevægelse.

Med OL-2000 blev legene til det, de egentlig havde været længe, nemlig til en transnational Sports- og Mediebegivenhed for den europaiske somakulturs udbredelse. I år 2000 EK havde de fundet deres endelige form. På trods af voldsom modstand, især i de mindre europæiske landes nationale komiteer, blev den Internationale Olympiske Komite i praksis uafhængig af nationale interesser. Paradoksalt nok var det en udvikling, der blev støttet af den Russiske Føderation, samt af de amerikanske, kinesiske og oceaniske fraktioner. Man $\emptyset$ nskede en mere konfliktfri og problemfri afvikling af Legene som forudsætning for, at de overhovedet kunne fortsætte. Motiverne var forskellige, men pegede i samme retning. Truslen om boykot, de finansielle vanskeligheder, de nødvendige garantier til hovedsponsorer og mediesammenslutninger medførte en stærk centralisering, selvom det olympiske Charter endnu ikke blev ændret. Det skete i 2004, hvor den såkaldte Organisationskomite fik stadfæstet sin magt.

Medierne havde med de voldsomme prisstigninger på rettigheder til transmission i 90'ernes olympiader i stigende grad satset på andre sportsarrangementer, især efter OL-1992 i Spanien.

\section{Forsiden af medaljen}

Guldmedalje fra:

Den europaiske somakulturs transnationale Sportsog Mediebegivenhed år $2000 E K$.

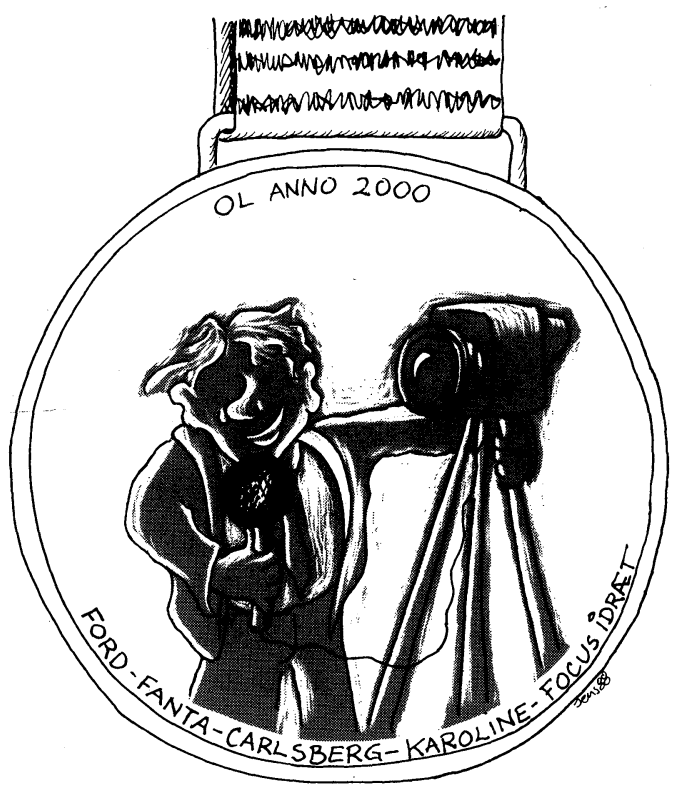


Americas Cup var, ligesom de store tennisturneringer, et indlysende valg efter, at den Russiske Føderation var gået ind $i$ havkapsejlads og tennis. I disse konkurrencer havde medierne en langt mere direkte indflydelse på tilrettelæggelsen, hvis de da ikke direkte selv organiserede dem, som det blev almindeligt i det sidste årti.

Den oceaniske mediesammenslutning finansierede således de nye 12-meter konkurrencer i det Indiske Ocean med Kina, Japan og det Oceaniske Statssamfund som deltagere. Den tilskuertræthed og »skærmlede «, der i industrimetropolerne gjorde sig gældende i den unge generation, krævede nye konkurrence- og sportsformer. TV-selskaberne talte ligefrem om en »saturationsgrænse «. Mæthed og overmæthed med sportsbegivenheder prægede de nye generationer. I Afrika, hvor medaljehøsten ikke stod i noget rimeligt forhold til de voldsomme omkostninger ved sportsudvikling, satsede det panafrikanske Broadcasting Network på de Afrikanske Kontinentallege, der var $\varnothing$ konomisk og ideologisk attraktive. OL-2000 har betydet, at det lykkedes at finde en ny formel for de Olympiske Lege.

Denne formel er stadigt gældende nu 20 år efter. Som tidligere nævnt hed formlen transnationalisme, centralisme og finansiel uafhængighed. Derved kunne Olympiaderne fortsat levere et kvalitetsprodukt i konkurrence med andre somakulturelle arrangementer. De Olympiske Lege har beholdt monopolet på den specielle kombination af internationalisme, elitisme og somakulturel universalisme, som havde udviklet sig over mere end 120 år.

Denne kombination havde vist sin tilpasningsevne til ekstremt varierende politiske og kulturelle forhold i det katastrofernes århundrede, som vi har forladt, og hvis følger vi stadig lider under. Jeg er ikke i tvivl om, at det var her, vi skal finde betydningen af OL-2000. Når vi ser tilbage på somakulturen i forrige århundrede, må vi spørge, hvorledes det overhovedet kunne lade sig gøre. Der var jo nogle, der allerede i 80'erne havde forudsagt Olympiadernes død. Men Olympiaden døde ikke. Den olympiske somakultur blev konsolideret. De voldsomme politiske og sociale ændringer, der fandt sted mellem 1992 og 2010 bidrog til denne konsolidering. Jeg tænker på opløsningen af det Østlige Socialistiske Hegemoni, som vi kalder det, og dannelsen af den Russiske Føderation, den Transkaukasiske Føderation og det nye Statsforbund i Centraleuropa. Jeg tænker på dannelsen af den Europæiske Union og det Oceaniske Statsforbund. Samtidigt udviklede det Teknotrone Samfund sig, dvs. teknik og informationssamfundet, selvom det kun skete i de nordlige og nogle få sydlige metropoler.

\section{Europas universalisme}

Jeg vil derfor tillade mig et historisk tilbageblik på de store linier i samfundsudviklingen i forrige århundrede. Hvordan kan vi i dag forstå de tendenser, der var på spil i den sociale struktur, der gik forud for det teknotrone samfund? 
Forrige århundrede var universaliseringens århundrede. Produktionskulturen i Amerika og Europa blev gjort universel. Det var den produktionskultur, der blev kaldt industrialismen eller kapitalismen. Kontrolkulturen blev ligeledes gjort universel (det, der blev kaldt politikken). Også den europæiske somakultur blev universel. Disse kulturformer udviklede sig fra spredte kimformer. Til sidst blev de til universalistiske kulturformer. Denne udvikling fandt sted i en gigantisk konkurrence med rivaliserende former for produktions- og kontrolkulturer. Med rivaliserende produktionskultur tænker jeg naturligvis på den såkaldte socialistiske produktionskultur, der fandtes i Sovjetunionen og Kina indtil 1996.

Olympiadens historie i forrige århundrede er historien om, hvorledes den europæiske somakultur blev universel. Det er tydeligt, at universalismen var den euroamerikanske civilisations hemmelige formel. Men der var, som vi ved i dag, grænser for denne universalisme. Det er derfor, jeg kaldte forrige århundrede for universaliseringens århundrede. Produktionskulturen og kontrolkulturen udviklede sig ikke til systemernes system, som nogle $\varnothing n-$ skede og som mange frygtede. Vores århundrede blev snarere til de mangfoldige blandingsformers århundrede. Universalismens træer voksede højt op, men ikke ind i himlen. Nye og blandede vækster opstod. Hegemonier blev opløst og nye alliancer opstod. Blandede produktionskulturer florerer i dag. Hånden og øjet samarbejder i dag med den bio-siliciumbaserede analoge hjerne.

Men indtil år 2000 fejrede universalismen sine triumfer. Det gjalt også den europæiske somakultur.

\section{De Olympiske Leges Historie 1896 til 2000}

Jeg har sagt, at OL-2000 var blevet til en transnational sports- og mediebegivenhed for den europæiske somakulturs udbredelse. De Olympiske Lege havde fundet deres endelige form: De var universalistiske i deres oprindelse, Olympismen i forrige århundrede er også historien om den europæiske somakulturs universalisering. Men de blev ikke universelle, som vi senere skal se. De Olympiske Leges historie i forrige århundrede er historien om, hvorledes den europæiske somakultur udviklede sig fra at være en lokal begivenhed til at blive en transnational festival. Det olympiske træ voksede højst, men ikke ind i himlen. I dag må det kæmpe med somakulturens mangfoldige andre vækster. Mit tilbageblik på Olympiadernes historie er, som jeg har understreget, kun een måde at fortælle denne historie på. Den første Olympiade i Grækenland i 1896 er historien om den nu næsten glemte Coubertins paradoksale og fikse ide. Han ville genoplive Antikkens olympiske lege ved hjælp af det døende engelske aristokratis somakultur. Det var et strålende eksempel på idesplejsning, hvor en myte splejses med et stykke virkelighed. Andre før ham havde koblet myten om Antikken med stumper af den europæiske kul- 
tur. Coubertin var egentlig 100 år for sent ude. Men dette fabeldyr, der kom ud af splejsningen, var kimen til den europæiske somakulturs universalisering. Det kunne ingen der overværede den første Olympiade ane. Det var en lokal græsk begivenhed. Men med de næste olympiader kobledes nye stumper til. Da olympiaderne blev afholdt i forbindelse med Verdensudstillingerne i Paris (1900), St. Louis (1904) og London (1908) blev ideen om en universel og humanistisk somakultur forbundet med ideen om en festival for det tekniske fremskridt. Olympiadens ide var en opfindelse ligeså enkel og genial som opfindelsen af flyvemaskinen på samme tid. Man sætter et sejlplan, en motor og en propel sammen, og man kan flyve. Coubertin satte somakultur, drømmen om græsk humanisme og det tekniske fremskridt sammen. Derved kunne den europæiske somakultur lette fra jorden.

Derpå blev den skandinaviske somakulturs opfindelse, den moderne gymnastik, koblet til. Olympismen blev til et kulturelt konglomorat. Da det europæiske system af nationalstater brød sammen i det, der fejlagtigt blev kaldt en verdenkrig, fik den nationale rivalisering sin blivende plads i Olympismen i næsten 100 år. Den store Europæiske Krig spaltede den europæiske overklasses kulturelle enhed og underklassernes drøm om en solidarisk internationalisme (»socialismen «), og truede også den olympiske ide.

Men olympismen overlevede, fordi den allerede nu var blevet til et af de første elementer i forrige århundredes massekultur. De nationale somakulturers eliter konkurrerede tiljublet af masserne ved Olympiaderne. I tiden mellem Krigene kom kvinderne med, og nye sportsgrene blev indføjet. Legene fik deres ceremoniel. Dyrkelsen af sportsrekorden begyndte. De olympiske lege som massernes kulturbegivenheder var som skabt for de nye massemedier, lydtransmission (»radio«) og todimensionel cinematografi (kaldet $»$ film «).

Berlinolympiaden var derfor afslutningen af den første epoke (1936). Og den varslede ejendommeligt nok de senere olympiaders universalisering. Alt var nu tilstede: Rekorden, den nationalistiske systemkonkurrence, filmen, masserne, sportens elite, radioen, den olympiske ide og den politiske udnyttelse af kroppenes festival. Men allerede nu var det antikke forbillede blevet til kirtsch.

Den europæiske somakultur havde fundet sin form i slutningen af Tiden Mellem Krigene. De konkurrerende eliters kroppe befandt sig i spændingsfeltet mellem ide og virkelighed, mellem renhed og udnyttelse, mellen skrøbelig internationalisme og blodig systemkonkurrence, mellem sporten som øjeblikkets begivenhed og den transmitterede sensation. Formlen for forrige århundredes somakultur var fundet. I samme øjeblik, som den olympiske formel var fundet, nemlig den universalistiske europæiske somakultur, brød den europæiske verden sammen endnu engang.

Bagefter var det en anden verden, og en ny olympisk formel skulle findes. Som professor Snout har sammenfattet det, lykkedes det for den olympiske bevægelse at genopstå og at tilpasse sig den bipolære verden. Den nye sy- 
stemkonkurrence på det magtpolitiske plan mellem USA og Sovjetunionen blev gentaget i de olympiske arenaer. Den åbne eller skjulte professionalisme holdt sit indtog. Kampen mellem sportens systemer begyndte. Den olympiske sport blev ligesom elitesporten som helhed til redskab for nationernes systemkonkurrence på det diplomatiske og ideologiske plan. Selv mindre nationer kunne gøre sig gældende gennem systematisk talentudvikling. Der er ingen tvivl om, at Legene derved vandt i attraktion for medierne. Men det var også en ny trussel mod legenes ideologi, ja eksistens. Legenes succes førte til den olympiske bevægelses krise, da nye politiske kræfter begyndte at bruge dem som et vindue mod verden. Når nationerne kunne benytte legene til deres politiske formål, hvorfor skulle ikke-nationerne så holde sig tilbage? Eller de undertrykte? Med München 1972 begyndte en krise, der varede over et årti. Terror og trussel om terror førte til, at Legene blev indkapslet i politiovervågning. Den ufredelige sameksistens mellem de store nationer førte til boykot og modboykot, som i Moskva og Los Angeles. En ny formel måtte findes. IOC udviklede med held sit eget diplomati, sin egen transnationale organisation, sine egne $\varnothing$ konomiske sanktioner. Den nye formel blev afprøvet ved de Olympiske Lege i Soul i 1988. Herfra er det let at trække linien frem til Manilla i år 2000. Formlen hed »globalisering «og »uafhængighed «.

\section{Somakulturen i dag}

Den model har holdt sig indtil i dag, 20 år efter. Men i dag er Olympismen blot een af mange somakulturelle modeller. Det holocinegrafiske medium, der blev brugt ved OL-2000, har fremmet de plastiske og holistiske kropsudtryk. De egner sig simpelthen bedre, fordi tilskuerens identifikation med anden-kroppens udtryk er næste total. Den virkning er stærkest i de »langsomme« discipliner. Ikke underligt, at de kommercielle mindre netværk hurtigt opdagede det nye marked. Nu hvor HCG-mediet er så udbredt, har de »todimensionale « og klassiske sportsarter fået en mærkbar konkurrence. Vi ser en ny global dansekultur udvikle sig gennem mødet mellem den afrikanske avantgardedans og den amerikanske stil. Også her har HCG-mediet spillet en rolle i udbredelsen. Når man selv med HCG-teknikken kan gå ind i billedet, ja selv blive eet med billedets bevægelser og smelte sammen med andenkroppen, behøves der ingen ydre identifikation. Transmissionen i 2015 fra den internationale festival for Soma-Drama i Venedig viste, at en ny universel somakultur er tænkelig. Måske kan de arkaiske somakulturer, der har overlevet, få en chance. Den europæiske somakultur gjorde alt andet til folkloristisk show. Det viste sig tidligt, at Indianere og Pygmæer ikke havde nogen plads i den olympiske bevægelse. Har de en plads i den ny bevægelse for Soma-Drama? Måske vil medierne slet ikke have samme betydning for den nye somakultur som før. Amazoniaden i Riga 2012 forb $\varnothing d$ simpelthen al mediedækning, og alligevel blev den nye kvindelige somakultur spredt gennem 
de personlige netværk. Jeg kan også nævne de nye subkulturer som »Spillerum « og »De fem sansers medieum «, der er på vej til at blive globale bevægelser stort set uden mediedækning.

Den Olympiske Bevægelse er idag kun een form for somakultur blandt en mangfoldighed af andre. Forrige århundrede var universaliseringens århundrede. Dette århundrede er mangfoldighedens århundrede. Jeg må dog advare mod fremtidsforskningen, den videnskabsgren, der var så populær i slutningen af forrige århundrede. Jeg skal derfor afstå fra at fremsætte prognoser.

\section{Litteraturliste}

- A. Snout: »The History of a Universal Idea«, Informatrix 01201 A. Disk 1, Chicago 2015.

- P. Messanger: »L'Evolution des Idees Culturelles«. Unidisk 25, Consigne 2018.

- I. Kiberian: Ocherk Olympischeskovo Dvizhenia«. Gosinfo 201, Disk 27, Moskva 2013.

- Jo. Frazer: »Somaculture and the Ideology of Supromacy«, Center of Somaculture, Disk 02, Copenhagen, 2018.

- H. Hügelstein: »The New Somaculture«, Cultsys 05X, Copenhagen 2019.

Søren Damkjær, lektor ved Institut for Kultursociologi, Københavns Universitet. 